\title{
Prevalens dan Faktor Risiko Infeksi Luka Operasi Pasca-bedah
}

\author{
Lina Haryanti, * Antonius H. Pudjiadi, * Evita Kariani B. Ifran, * Amir Thayeb, ** Idham \\ Amir, * Badriul Hegar* \\ *Departemen Ilmu Kesehatan Anak Fakultas Kedokteran Universitas Indonesia, Jakarta \\ **Departemen Ilmu Bedah Fakultas Kedokteran Universitas Indonesia, Jakarta
}

\begin{abstract}
Latar belakang. Infeksi luka operasi (ILO) merupakan salah satu komplikasi pasca-bedah abdomen yang dapat meningkatkan morbiditas, mortalitas, dan biaya pengobatan. Diperlukan data prevalens ILO pascabedah abdomen pada anak di RSCM dan faktor risiko yang memengaruhinya.

Tujuan. Mengetahui prevalens dan karakteristik ILO serta hubungan antara usia, jenis kelamin, status nutrisi, skor PELOD, skor ASA, jenis operasi, kategori luka operasi, dan lama operasi dengan ILO pascabedah abdomen pada anak.

Metode. Data penelitian dari rekam medis tahun 2009-2011 pada anak pasca-bedah abdomen dengan besar sampel 180 subjek. Analisis statistik dengan uji Chi-square/Fisher dan regresi logistik.

Hasil. Prevalens ILO pasca-bedah abdomen pada anak di RSCM selama tiga tahun 7,2\%. Infeksi luka operasi merupakan 23,6\% dari total infeksi nosokomial pasca-bedah abdomen di RSCM. Enam dari 13 subjek dengan ILO mengalami sepsis dan 2 di antaranya meninggal karena sepsis. Tiga jenis ILO, yaitu ILO insisional superfisial ( 9 subjek), ILO insisional dalam ( 2 subjek), dan ILO organ ( 2 subjek). Terdapat hubungan bermakna antara jenis operasi cito dengan ILO (p=0,007, RO 4,72;95\%IK 1,54-14,42). Sedangkan variabel lainnya tidak berhubungan bermakna.

Kesimpulan. Jenis operasi cito merupakan faktor risiko ILO pasca-bedah abdomen pada anak di RSCM Jakarta. Perlu penelitian prospektif dengan sampel yang lebih besar. Sari Pediatri 2013;15(4):207-12.
\end{abstract}

Kata kunci: infeksi luka operasi, pasca-bedah abdomen, faktor risiko

$\mathrm{I}$ nfeksi luka operasi (ILO) merupakan salah satu komplikasi pasca-bedah abdomen dan infeksi nosokomial yang sering terjadi pada pasien bedah. Survei oleh WHO menunjukkan 5\%-34\% dari total infeksi nosokomial adalah ILO. ${ }^{1}$ Penelitian

\section{Alamat korespondensi:}

Dr. Lina Haryanti, Sp.A. Jl. Pancuran Gg. Kliwon 113, Cirebon, Jabar, 45122. Telp. (0231) 234859. E-mail: lina_euy@yahoo.com di Vietnam dilaporkan insiden ILO 10,9\% dari 697 pasien. Bedah abdomen terbukti berisiko 4,46 kali mengalami ILO dibanding jenis tindakan bedah lainnya. ${ }^{2}$ Pencegahan dan Pengendalian Infeksi Rumah Sakit (PPIRS) Rumah Sakit Cipto Mangunkusumo (RSCM) melaporkan insiden ILO pada tahun 2011 di ruang rawat bedah anak 4,3\%. ${ }^{3}$ Departemen Ilmu Bedah RSCM melaporkan insidens ILO pasca-bedah abdomen pada pasien dewasa $10 \%$ sejak 1 Januari 
sampai 28 Februari 2007. ${ }^{4}$

Penelitian faktor risiko ILO pasca-bedah pada anak di Spanyol dengan meneliti variabel usia, jenis kelamin, lama rawat pra-bedah, kategori luka operasi, lama operasi, penggunaan antibiotik profilaksis, lama penggunaan kateter vena sentral, lama penggunaan kateter vena perifer, lama penggunaan kateter urin, lama penggunaan ventilator, jumlah diagnosis, dan jenis operasi. Terdapat hubungan bermakna antara variabel tersebut dengan ILO kecuali usia, jenis kelamin, lama rawat pra-bedah, penggunaan antibiotik profilaksis, dan penggunaan ventilator. ${ }^{5}$ Jenis operasi cito juga terbukti sebagai salah satu faktor risiko ILO. Murtaza $\mathrm{dkk}^{6}$ di Pakistan melaporkan prevalens ILO pasca-laparotomi cito lebih tinggi dibanding pascalaparotomi elektif.

Prognosis mortalitas pasien pasca-bedah yang dirawat di ruang intensif dapat diukur dengan skor PELOD (Pediatric Logistic Organ Dysfunction). ${ }^{7}$ Derajat berat penyakit sebelum operasi dapat diukur dengan skor ASA (American Society of Anesthesiologists). ${ }^{8}$ Kedua skor tersebut menggambarkan kondisi pasien pra dan pasca-bedah. Tujuan penelitian ini untuk mengetahui prevalens ILO, karakteristik subjek ILO, karakteristik ILO, serta hubungan antara usia, jenis kelamin, status nutrisi, skor PELOD, skor ASA, jenis operasi, kategori luka operasi, dan lama operasi dengan ILO pasca-bedah abdomen pada anak.

\section{Metode}

Penelitian potong lintang deskriptif analitik menggunakan data sekunder dari rekam medis (1 Januari 2009-31 Desember 2011) dengan besar sampel 180 subjek. Subjek adalah anak usia $<18$ tahun pascabedah abdomen di RSCM dengan skor ASA 1-4. Kriteria eksklusi pada penelitian ini adalah subjek yang mengalami infeksi pra-bedah yang belum teratasi saat operasi dan data rekam medis tidak lengkap. Variabel bebas adalah usia, jenis kelamin, status nutrisi, skor PELOD, skor ASA, jenis operasi, kategori luka operasi, dan lama operasi. Sedangkan variabel tergantung adalah ILO pasca-bedah abdomen.

Infeksi luka operasi adalah infeksi lokal di abdomen yang berkaitan langsung dengan tindakan bedah abdomen, timbul dalam waktu 30 hari pascabedah selama pasien dirawat di rumah sakit, ditandai terdapat sekret purulen, abses, atau selulitis pada luka operasi, dan dapat disertai komplikasi akibat infeksi luka operasi, yaitu adhesi, fistel, prolaps stoma, leakage anastomosis, burst abdomen, dan perforasi. ${ }^{9}$ Hubungan antara variabel bebas dengan variabel tergantung digunakan uji chi-square/Fisher, kemudian variabel yang memiliki nilai $\mathrm{p}<0,25$ atau rasio Odds $\geq 2,0$ atau $\leq 0,5$ dilakukan uji multivariat (regresi logistik). Hubungan dikatakan bermakna bila $p<0,05$.

\section{Hasil}

Proporsi jenis kelamin laki-laki tidak jauh berbeda dengan perempuan $(1,3: 1)$. Nilai median usia 10,1 bulan dengan rentang usia 1 hari hingga 16,6 tahun. Sebagian besar diagnosis adalah kelainan kongenital $(91,7 \%)$, seperti atresia ani $(48,9 \%)$ dan Morbus Hirschsprung (22,8\%). Terdapat 43 subjek $(23,9 \%)$ yang memiliki 3 atau lebih diagnosis saat pulang dari rumah sakit. Terdapat 11 subjek $(6,1 \%)$ dengan penyakit jantung bawaan dan 4 dari 11 subjek tersebut diduga memiliki sindrom tertentu. Sindrom Down terdapat pada 2 subjek.

Tabel 1. Karakteristik subjek penelitian $(\mathrm{n}=180)$

\begin{tabular}{lc}
\hline Karakteristik subjek & Jumlah $\mathrm{n}(\%)$ \\
\hline Jenis kelamin & \\
Laki-laki & $103(57,2)$ \\
Perempuan & $77(42,8)$ \\
Usia & \\
Neonatus & $48(26,7)$ \\
Bayi & $49(27,2)$ \\
Balita & $54(30)$ \\
Anak & $29(16,1)$ \\
Status gizi & \\
Buruk & $6(3,3)$ \\
Kurang & $68(37,8)$ \\
Baik & $99(55)$ \\
Overweight & $6(3,3)$ \\
Obesitas & $1(0,6)$ \\
Skor PELOD & \\
$\geq 20$ (berat) & $14(7,8)$ \\
$10-19$ (sedang) & $63(35)$ \\
$<10$ (ringan) & $103(57,2)$ \\
Skor ASA & \\
1 & $29(16,1)$ \\
2 & $110(61,1)$ \\
3 & $40(22,2)$ \\
4 & $1(0,6)$ \\
\hline
\end{tabular}


Lina Haryanti dkk: Prevalens dan faktor risiko infeksi luka operasi pasca-bedah

Tabel 1. Karakteristik subjek penelitian $(\mathrm{n}=180)$ (sambungan)

\begin{tabular}{|c|c|}
\hline Karakteristik subjek & Jumlah $\mathrm{n}(\%)$ \\
\hline \multicolumn{2}{|l|}{ Jenis operasi } \\
\hline Cito & $33(18,3)$ \\
\hline Elektif & $147(81,7)$ \\
\hline \multicolumn{2}{|l|}{ Kategori luka operasi } \\
\hline Bersih & $52(28,9)$ \\
\hline Bersih tercemar & $100(55,6)$ \\
\hline Tercemar & $22(12,2)$ \\
\hline Kotor & $6(3,3)$ \\
\hline \multicolumn{2}{|l|}{ Lama operasi (jam) } \\
\hline$\leq 2$ & $100(55,6)$ \\
\hline$>2$ & $80(44,4)$ \\
\hline \multicolumn{2}{|c|}{ Penggunaan antibiotik profilaksis } \\
\hline $\mathrm{Ya}$ & $10(5,6)$ \\
\hline Tidak & $170(94,4)$ \\
\hline \multicolumn{2}{|c|}{$\begin{array}{l}\text { Penggunaan antibiotik terapeutik } \\
\text { pra-bedah abdomen }\end{array}$} \\
\hline $\mathrm{Ya}$ & $9(5)$ \\
\hline Tidak & $171(95)$ \\
\hline \multicolumn{2}{|c|}{ Lama penggunaan kateter vena sentral (hari) } \\
\hline Tidak menggunakan & $123(68,3)$ \\
\hline $1-7$ & $29(16,1)$ \\
\hline$>7$ & $28(15,6)$ \\
\hline \multicolumn{2}{|c|}{ Lama penggunaan kateter vena perifer (hari) } \\
\hline$\leq 3$ & $111(61,7)$ \\
\hline$>3$ & $69(38,3)$ \\
\hline \multicolumn{2}{|c|}{ Lama penggunaan kateter urin (hari) } \\
\hline Tidak menggunakan & $19(10,5)$ \\
\hline $1-7$ & $120(66,7)$ \\
\hline$>7$ hari & $41(22,8)$ \\
\hline \multicolumn{2}{|c|}{ Lamanya penggunaan ventilator (hari) } \\
\hline Tidak menggunakan & $140(77,8)$ \\
\hline $1-7 \quad 00$ & $31(17,2)$ \\
\hline$>7$ & $9(5)$ \\
\hline \multicolumn{2}{|l|}{ Perawatan pasca-bedah } \\
\hline NICU & $20(11,1)$ \\
\hline PICU & $67(37,2)$ \\
\hline ICU IGD & $3(1,7)$ \\
\hline ICU & $1(0,6)$ \\
\hline Ruang rawat Bedah Anak & $88(48,9)$ \\
\hline Ruang rawat anak & $1(0,6)$ \\
\hline \multicolumn{2}{|l|}{ Luaran } \\
\hline Sembuh & $160(88,9)$ \\
\hline Pulang paksa & $6(3,3)$ \\
\hline Meninggal & $14(7,8)$ \\
\hline \multicolumn{2}{|l|}{ Komplikasi } \\
\hline Sepsis & $13 / 14$ \\
\hline Hipertensi pulmonal & $1 / 14$ \\
\hline
\end{tabular}

Tabel 2. Karakteristik subjek dengan ILO ( $\mathrm{n}=13)$

\begin{tabular}{|c|c|}
\hline Karakteristik & umlah (n) \\
\hline \multicolumn{2}{|l|}{ Usia } \\
\hline Neonatus & $4 / 13$ \\
\hline Bayi & $2 / 13$ \\
\hline Balita & $5 / 13$ \\
\hline Anak & $2 / 13$ \\
\hline \multicolumn{2}{|l|}{ Jenis kelamin } \\
\hline Laki-laki & $10 / 13$ \\
\hline Perempuan & $3 / 13$ \\
\hline \multicolumn{2}{|l|}{ Status nutrisi } \\
\hline Kurang & $4 / 13$ \\
\hline Baik & $9 / 13$ \\
\hline \multicolumn{2}{|l|}{ Skor ASA } \\
\hline ASA 2 & $9 / 13$ \\
\hline ASA 3 & $4 / 13$ \\
\hline \multicolumn{2}{|l|}{ Skor PELOD } \\
\hline Ringan & $6 / 13$ \\
\hline Sedang & $7 / 13$ \\
\hline \multicolumn{2}{|l|}{ Jenis operasi } \\
\hline Cito & $4 / 13$ \\
\hline Elektif & $9 / 13$ \\
\hline \multicolumn{2}{|l|}{ Kategori luka operasi } \\
\hline Bersih & $2 / 13$ \\
\hline Bersih tercemar & $7 / 13$ \\
\hline Tercemar & $3 / 13$ \\
\hline Kotor & $1 / 13$ \\
\hline \multicolumn{2}{|l|}{ Lama operasi (jam) } \\
\hline$\leq 2$ & $5 / 13$ \\
\hline$>2$ & $8 / 13$ \\
\hline \multicolumn{2}{|l|}{ Diagnosis } \\
\hline Atresia ani dengan fistel & $3 / 13$ \\
\hline Atresia ani tanpa fistel & $1 / 13$ \\
\hline Atresia esophagus dengan fistel trakeoesofagus & Is $1 / 13$ \\
\hline Atresia ileum & $2 / 13$ \\
\hline Divertikel Meckel & $1 / 13$ \\
\hline Luka tusuk abdomen & $1 / 13$ \\
\hline Morbus Hirschsprung & $4 / 13$ \\
\hline \multicolumn{2}{|l|}{ Jenis tindakan bedah abdomen } \\
\hline Laparotomi, prosedur Duhamel & $1 / 13$ \\
\hline Laparotomi eksplorasi, PSA & $2 / 13$ \\
\hline Laparotomi eksplorasi, kolostomi & $2 / 13$ \\
\hline Laparotomi eksplorasi, prosedur Meckulitz & $1 / 13$ \\
\hline Laparotomi, prosedur Santuli & $1 / 13$ \\
\hline Laparotomi eksplorasi & $1 / 13$ \\
\hline Laparotomi, prosedur Soave & $2 / 13$ \\
\hline Torakotomi, gastrostomi, reseksi anastomosis & $1 / 13$ \\
\hline Tutup stoma & $2 / 13$ \\
\hline Infeksi luka operasi dengan sepsis & $6 / 13$ \\
\hline Meninggal & $2 / 13$ \\
\hline
\end{tabular}


Prevalensi ILO 13 dari 180 subjek (7,2\%). Diagnosis terbanyak pada subjek dengan ILO adalah Morbus Hirschsprung ( 4 subjek) dan atresia ani ( 4 subjek) (Tabel 2). Atresia ani dengan fistel dibanding tanpa fistel yaitu 3:1. Keempat subjek dengan Morbus Hirschsprung berusia $\geq 1$ tahun. Dua dari 4 subjek tersebut meninggal dengan sepsis sebagai penyebab kematian.

Tujuh dari 13 subjek mengalami komplikasi luka operasi dan memerlukan reoperasi. Hanya 6 subjek dengan ILO yang dilakukan kultur pus dengan hasil Klebsiella pneumonia (2 subjek), E. coli (2 subjek), Pseudomonas sp. (1 subjek), dan tidak tumbuh mikroorganisme (1 subjek). Jenis ILO terdiri dari tiga macam, yaitu ILO insisional superfisial (9 subjek), ILO insisional dalam (2 subjek), dan ILO organ (2 subjek).

Tabel 3 menunjukkan tidak terdapat hubungan bermakna ( $p>0,05)$ antara variabel bebas dengan ILO pasca-bedah abdomen. Variabel yang dimasukkan ke dalam analisis multivariat adalah jenis kelamin, jenis operasi, lama operasi, dan kategori luka operasi. Hasil analisis multivariat menunjukkan adanya hubungan bermakna antara jenis operasi cito dengan ILO (Tabel 4).

Tabel 4. Analisis multivariat faktor risiko ILO

\begin{tabular}{lccc}
\hline Faktor risiko & $\mathrm{p}$ & $\mathrm{RO}$ & IK 95\% \\
\hline $\begin{array}{l}\text { Langkah 3 } \\
\text { Jenis operasi cito }\end{array}$ & 0,007 & 4,72 & $(1,54-14,42)$ \\
\hline
\end{tabular}

\section{Pembahasan}

Prevalens ILO penelitian kami lebih tinggi jika dibandingkan dengan Amerika Serikat (2\%$4 \%)$, tetapi lebih rendah jika dibandingkan dengan Vietnam $(10,9 \%)$, dan hampir serupa dengan Brazil $(6,7 \%))^{2,10}$ Perbedaan prevalens ILO tersebut juga disebabkan adanya perbedaan

Tabel 3. Analisis bivariat faktor risiko ILO $(\mathrm{n}=180)$

\begin{tabular}{|c|c|c|c|c|c|c|c|}
\hline \multirow[t]{2}{*}{ Faktor risiko } & \multicolumn{2}{|c|}{ Infeksi } & \multicolumn{2}{|c|}{ Tidak infeksi } & \multirow[t]{2}{*}{$\mathrm{p}$} & \multirow[t]{2}{*}{$\mathrm{RO}$} & \multirow{2}{*}{$\begin{array}{l}\text { IK 95\% } \\
\text { min-mak }\end{array}$} \\
\hline & $\mathrm{n}$ & $\%$ & $\mathrm{n}$ & $\%$ & & & \\
\hline \multicolumn{8}{|l|}{ Usia (tahun) } \\
\hline$<1$ & 6 & 46,2 & 91 & 54,5 & $0,561^{*}$ & 0,72 & $0,23-2,22$ \\
\hline$\geq 1$ & 7 & 53,8 & 76 & 45,5 & & Ref & \\
\hline \multicolumn{8}{|l|}{ Jenis kelamin } \\
\hline Laki-laki & 10 & 76,9 & 93 & 55,7 & $0,136^{*}$ & 2,65 & $0,70-9,99$ \\
\hline Perempuan & 3 & 23,1 & 74 & 44,3 & & Ref & \\
\hline \multicolumn{8}{|l|}{ Status nutrisi } \\
\hline Gizi kurang & 4 & 30,8 & 70 & 41,9 & $0,431^{*}$ & 0,62 & $0,18-2,08$ \\
\hline Gizi baik & 9 & 69,2 & 97 & 58,1 & & Ref & \\
\hline \multicolumn{8}{|l|}{ Skor PELOD } \\
\hline Ringan $(<10)$ & 6 & 46,2 & 97 & 58,1 & $0,402^{*}$ & 0,62 & $0,19-1,92$ \\
\hline Sedang (10-19) & 7 & 53,8 & 70 & 41,9 & & Ref & \\
\hline \multicolumn{8}{|l|}{ Skor ASA } \\
\hline ASA 2 & 9 & 69,2 & 130 & 77,8 & $0,497^{* *}$ & 0,64 & $0,19-2,19$ \\
\hline ASA 3 & 4 & 30,8 & 37 & 22,2 & & Ref & \\
\hline \multicolumn{8}{|l|}{ Jenis operasi } \\
\hline Cito & 4 & 30,8 & 29 & 17,4 & $0,261^{* *}$ & 2,12 & $0,61-7,34$ \\
\hline Elektif & 9 & 69,2 & 138 & 82,6 & & Ref & \\
\hline \multicolumn{8}{|l|}{ Lama operasi (jam) } \\
\hline$>2$ & 8 & 61,5 & 72 & 43,1 & $0,198^{*}$ & 2,11 & $0,66-6,72$ \\
\hline$\leq 2$ & 5 & 38,5 & 95 & 56,9 & & Ref & \\
\hline \multicolumn{8}{|l|}{ Kategori luka operasi } \\
\hline Bersih dan Bersih tercemar & 9 & 69,2 & 144 & 86,2 & $0,110^{* *}$ & 0,36 & $0,10-1,26$ \\
\hline Tercemar dan Kotor & 4 & 30,8 & 23 & 13,8 & & Ref & \\
\hline
\end{tabular}


usia subjek dan jenis tindakan bedah. Kelompok usia subjek terbanyak adalah usia balita karena diagnosis terbanyak adalah kelainan kongenital $(91,7 \%)$ yang memerlukan intervensi bedah pada usia dini. Tidak terdapat hubungan antara usia dengan ILO. Hasil tersebut serupa dengan penelitian oleh Cassanova $\mathrm{dkk}^{5}$ di Spanyol, PorrasHernandez dkk ${ }^{11}$ di Meksiko, Duque-Estrada $\mathrm{dkk}^{10}$ di Brazil.

Perbandingan jenis kelamin subjek dengan ILO antara laki-laki dan perempuan yaitu 3,3:1. Sebagian besar diagnosis subjek dengan ILO adalah Morbus Hirschsprung dan atresia ani yang secara epidemiologi laki-laki lebih banyak dibanding perempuan. ${ }^{12}$ Tidak terdapat hubungan antara jenis kelamin dengan ILO. Hasil tersebut serupa dengan penelitian oleh Cassanova $\mathrm{dkk}^{5}$ di Spanyol dan Duque-estrada dkk ${ }^{10}$ di Brazil. Status nutrisi diduga berhubungan dengan ILO pascabedah abdomen, tetapi tidak didapatkan hubungan pada penelitian kami. Serupa dengan penelitian oleh Porras-Hernandez $\mathrm{dkk}^{11}$ di Meksiko yang dilaporkan tidak ada hubungan antara status nutrisi berdasarkan antropometri dengan ILO.

Subjek dengan ILO memiliki skor PELOD ringan dan sedang. Tidak terdapat hubungan antara skor PELOD dengan ILO. Pada penelitian kami, skor PELOD hanya dihitung satu kali sehingga tidak menggambarkan perburukan selama perawatan. Leteurtre $\mathrm{dkk}^{7}$ di Perancis melaporkan bahwa skor PELOD dapat memprediksi prognosis dan mortalitas apabila diperiksa secara berkala.

Subjek dengan ILO memiliki skor ASA 2 dan 3. Tidak terdapat hubungan antara skor ASA dengan ILO. National Nosocomial Infection Surveillance (NNIS) Amerika Serikat memasukkan skor ASA sebagai salah satu faktor risiko ILO ${ }^{8}$ Hasil penelitian tersebut serupa dengan penelitian oleh Duque-Estrada $\mathrm{dkk}^{10}$ di Brazil dan Porras-Hernandez dkk ${ }^{11}$ di Meksiko.

Terdapat hubungan antara jenis operasi cito dengan ILO pasca-bedah abdomen. Hasil tersebut serupa dengan penelitian oleh Murtaza $\mathrm{dkk}^{6}$ di Pakistan dan Sorensen $\mathrm{dkk}^{13}$ di Denmark. Operasi cito pada anak sebagian besar dilakukan pada kasus obstruksi usus kongenital. Obstruksi usus dapat menimbulkan kondisi pertumbuhan bakteri berlebih atau terjadi hipoksia jaringan sehingga mudah terjadi ILO dan proses penyembuhan luka menjadi terlambat. ${ }^{13}$ Tidak terdapat hubungan antara lama operasi dengan ILO. Hasil penelitian ini berbeda dengan penelitian yang dilakukan oleh Cassanova $\mathrm{dkk}^{5}$ di Spanyol dan CDC Amerika Serikat, walaupun sama dalam menggunakan batas waktu dua jam. ${ }^{8}$

Prevalens ILO pasca-bedah abdomen pada anak masih tinggi, maka diperlukan suatu panduan tata laksana pasien anak pra dan pasca-bedah. Sebagai dokter spesialis anak harus memperhatikan dan menuliskan faktor risiko yang ada pada pasien saat membuat toleransi operasi dan memberi penjelasan kepada orangtua pasien tentang risiko ILO pasca-bedah abdomen. Perlu penelitian lebih lanjut di RSCM dan membuat sistem skor faktor risiko ILO dengan sampel lebih besar dan dilakukan secara prospektif.

\section{Daftar pustaka}

1. Singhal H, Kaur K, Zammit C. Wound infection. (Diakses pada tanggal 5 April 2008). Diunduh dari: http://www.emedicine.com.

2. Nguyen D, MacLeod WB, Phung DC. Incidence and predictors of surgical site infections in Vietnam. Infect Control Hosp Epidemiol 2001;22:485-92.

3. Pencegahan dan Pengendalian Infeksi Rumah Sakit RSCM. Data HAI tahun 2011. Jakarta: Rumah Sakit Umum Pusat Nasional Dr. Cipto Mangunkusumo 2011.

4. Kartadinata R. Surgical site infection operasi abdomen di RSCM (tesis). Jakarta: Departemen Ilmu Bedah Fakultas Kedokteran Universitas Indonesia RSUPN Dr. Cipto Mangunkusumo; 2007.

5. Cassanova J, Herruzo R, Di'ez J. Risk factors for surgical site infection in children. Infect Control Hosp Epidemiol 2006;27:709-15.

6. Murtaza B, Saeed S, Sharif MA. Postoperative complications in emergency versus elective laparotomies at a peripheral hospital. J Ayub Med Coll Abbottabad 2010;22:42-7.

7. Leteurtre S, Duhamel A, Grandbastien B. Daily estimation of the severity of multiple organ dysfunction syndrome in critically ill children. CMAJ 2010;182:11817.

8. Delgado-Rodriguez M, Sillero-Arenas M, MedinaCuadros M, Martinez-Galleg G. Nosocomial infections in surgical patients: comparison of two measures of intrinsic patient risk. Infect Control Hosp Epidemiol 1997;18:19-23.

9. Dayton MT. Surgical complications. Dalam: Townsend CM, Beauchamp RD, Evers BM, Mattox KL, penyunting. 
Sabiston Textbook of Surgery The Biological Basis of Modern Surgical Practice.Edisi ke-17. Philadelphia: Saunders; 2004. h. 297-325.

10. Duque-Estrada EO, Duarte MR, Rodrigues DM, Raphael MD. Wound infections in pediatric surgery: a study of 575 patients in a university hospital. Pediatr Surg Int 2003;19:436-8.

11. Porras-Hernandez JD, Vilar-Compte D, Cashat-Cruz M, Ordorica-Flores RM, Bracho-Blanchet E, Avila-Figueroa C. A prospective study of surgical site infections in a pediatric hospital in Mexico City. Am J Infect Control 2003;31:302-8.

12. Pena A, Levitt M, Corman ML. Pediatric surgical problems. Dalam: Corman ML, penyunting. Colon and Rectal Surgery. Edisi ke-5. Philadelphia: Lippincott Williams \& Wilkins; 2005. h. 555-65.

13. Sorensen LT, Hemmingsen U, Kallehave F, WilleJorgensen P, Kjaergaard J, Moller LN, dkk. Risk factors for tissue and wound complications in gastrointestinal surgery. Ann Surg 2005;241:654-8. 